anales de psicología / annals of psychology

2019, vol. 35, nº 1 (january), 166-174

http://dx.doi.org/10.6018/analesps.35.1.329211
(C) Copyright 2019: Editum. Servicio de Publicaciones de la Universidad de Murcia. Murcia (Spain) ISSN print edition: 0212-9728. ISSN on line edition (http://revistas.um.es/analesps): 1695-2294

On line edition License Creative Commons 4.0: BY-NC-ND

\title{
Scientific communication or a qualification for an academic career? What use is publishing papers in psychology journals?
}

\author{
1 INGENIO (CSIC-UPV), Universitat Politècnica de València (Spain)
2 Universitat de V alència (Spain) \\ 2 Universitat de València (Spain)
}

Julia Osca-Lluch ${ }^{1, *}$, Francisco González-Sala ${ }^{2}$, Julia Haba-Osca ${ }^{2}$, Francisco Tortosa ${ }^{2}$, and María Peñaranda-Ortega ${ }^{3}$

Título: Comunicación científica o cualificación para una carrera académica: ¿Qué uso tienen los artículos en las revistas de psicología?

Resumen: Este trabajo analiza todas las revistas de psicología que se hallan incluidas en las diversas categorías de las bases de datos JCR (SCI y SSCI) y SJR durante el periodo 2014-2016 para tratar de identificar las revistas que se encuentran mejor posicionadas en esta disciplina, sus especialidades y los países con mayor número de publicaciones indexados en dichas bases de datos. Método: Se analizó la distribución de revistas por países, cuartil y categoría para determinar la posición de las revistas en cada país e identificar los que tuviesen mayor cantidad de revistas de excelencia en psicología en la escena internacional. Resultados: Estados Unidos y Reino Unido tienen el mayor número de revistas incluidas en las bases de datos, así como Holanda, Alemania, Francia y España. Sólo 11 países poseen revistas en el cuartil 1 en la base de datos JCR, y 14 en SRJ. Conclusiones: Como resultado de la aplicación de los nuevos criterios evaluadores en la investigación psicológica en España, este trabajo aborda las dificultades y consecuencias que algunas de estas medidas pueden tener para la supervivencia de las revistas de psicología que no se encuentran posicionadas en cuartil 1 o 2 en las bases de datos usadas para la evaluación de los profesionales investigadores en esta disciplina

Palabras clave: Revistas de psicología; Revistas especializadas; JCR; SJR; Evaluación científica; Psicología.

\section{Introduction}

Spanish psychology is nowadays a strong reality as a discipline, but it faces a number of threats and challenges. The gradual definition of the European Area has resulted in growing internationalisation and proactive quality policies, particularly quality assessment. Concerning internationalisation -and we shall not attempt to discuss this elusive concept (Buela-Casal \& Zych, 2012) the implementation of an evaluation policy based on international indicators by Spain's evaluation agencies -Agencia Nacional de Evaluación y Prospectiva (ANEP), Comisión Nacional Evaluadora de la Actividad Investigadora (CNEAI), and Agencia Nacional de Evaluación de la Calidad y Acreditación (ANECA) - was key (Moreno-Pulido, López-González, Rubio-Garay, Saúl \& Sánchez-Elvira-Paniagua, 2013). The three agencies believe the number of publications in the Web of Science (WOS) and their impact factor (Jiménez-Contreras, Robinson-García \& Cabezas-Clavijo, 2011) to be significantly relevant, and they give preference and even exclusivity to the number of

* Correspondence address [Dirección para correspondencia] Julia Osca-Lluch. INGENIO (CSIC-UPV), Universitat Politècnica de València, Ciudad Politècnica de la Innovación, Camino de Vera, s/n, 46022, Valencia (Spain). E-mail: juosllu@ingenio.upv.es

(Article received: 26-4-2018; revised: 12-5-2018; accepted: 3-7-2018)
Abstract: This paper analyses all psychology journals included in the different categories of the JCR (SCI and SSCI) and SJR databases during the period 2014-2016 in order to identify the journals that are better positioned in the discipline, and the specialities and countries with the highest number of publications indexed in such databases. Method: The distribution of psychology journals by country, quartile, and subject category was studied in order to determine the total number and position of journals in each country, and to identify the countries with more journals of 'excellence' in psychology in the international scene. Results: The United States and the United Kingdom had the highest number of journals included in the databases, as well as the Netherlands, Germany, France and Spain. Only 11 countries have psychology journals in quartile 1 in JCR, and 14 in SJR databases. Conclusions: As a result of the application of new evaluation criteria in psychology research in Spain, the paper addresses the difficulties and consequences that some of these measures may have for the survival of psychology journals that do not have a position in quartile 1 or 2 in the databases used for the evaluation of professionals' research in this discipline.

Keywords: Psychology journals; Specialised journals; JCR; SJR; Scientific evaluation; Psychology.

articles published in journals in top JCR positions, i.e. quartiles 1 and 2.

Citation analysis and impact factor have become the gold standard (Torres-Salinas \& Cabezas-Clavijo, 2013) in the assessment of journals, researchers, lecturers, interns, universities, projects, research groups, and $\mathrm{PhD}$ programmes (BuelaCasal, 2010; Buela-Casal, Quevedo \& Guillén, 2015; Gordillo, Gonzáles-Marqués \& Muñiz, 2004; Musi-Lechuga, Olivas-Ávila \& Buela-Casal, 2009; Buela-Casal \& Sierra, 2007; Olivas-Ávila \& Musi-Lechuga, 2010; Ortiz \& Mora, 2013; Torres-Salinas, Delgado-López-Cózar, García-MorenoTorres \& Herrera, 2011).

The pressure to publish in journals in the first two quartiles has resulted in falsification and manipulation of research and researcher résumés. Not only typical of Spain, this situation has given way to a genuine 'culture of scientific publication in impact factor journals' to the detriment of book publishing, and has even changed the traditional format of $\mathrm{PhD}$ dissertations (Buela-Casal, 2014), although it is a highly controversial measure. This culture has caused many to consider the Impact Factor 'irreplaceable' (Brody, 2013), 'appropriate' Moed et al., 2012), and certainly 'transparent and easy to use' as a way of collecting and interpreting (Pudovkin \& Garfield, 2012), while for others it has come to be seen as the impact factor style of thinking' (Fernández-Ríos \& Rodríguez-Díaz, 2014), 'publicationitis' (Perceval \& Fornieles, 2008), 'impacti- 
tis' (Van Diest, Holzel, Burnett \& Crocker, 2011), 'a source of frustration' (Laufer, 2013), ‘tyranny' (García, 2014), or 'impactolatry' (Camí, 1997).

Whichever the case, the stakeholders involved in the management, financing and implementation of scientific activities, as well as researcher employers, want the quality and the impact of scientific contributions to be objectively assessed. Yet, identifying the best journals in a scientific area or specialty is a very complex task (Osca-Lluch, 2005).

Intended for literature search and retrieval, a tool like the WoS has been almost exclusively used for the purpose of evaluating quality in scientific papers and journals (RuizPérez, Delgado \& Jiménez-Contreras, 2006; Medina-Muñoz \& Estrada-Lorenzo, 2015). Furthermore, the impact factor of a journal is directly used to add value to its articles, regardless of their actual contents; in fact, it is the means quartile 1 and 2 journals- which gives value to the articles (CNEAI, 2016).

The main goal of this paper is to analyse all psychology journals included in the different categories of the JCR (SCI and SSCI) databases in 2014, 2015 and 2016 in order to determine which journals are better positioned in the discipline, what specialities have the largest number of publications in the database, and which countries have the highest publication rates. As specific objectives, the study intends to explore the distribution of psychology journals by country, quartile, and subject category with a view to determining the total number and position of journals in each country and identifying the countries with more journals of excellence in psychology in the international context.

\section{Method}

The psychology journals of the Journal Citation Reports (SCI and SSCI) databases from Clarivate Analytics and Scimago Journal \& Country Rank (SJR), that gathers the information of the journals included in Scopus databases from the group Elsevier were analysed. More specifically, their distribution by country, quartile and subject area was examined for the journals included in the latest database, i.e. 2014, 2015 and 2016.

The number of journals was determined by consulting all psychology journals included in the 11 subject categories in which journals in this discipline are classified in the JCR (SCI and SSCI) databases: Psychology, Psychology Applied, Psychology Biological, Psychology Clinical, Psychology Developmental, Psychology Educational, Psychology Experimental, Psychology Mathematical, Psychology Multidisciplinary, Psychology Psychoanalysis and Psychology Social. And, the 7 subject categories in which psychology journals are included in the SJR databases: Applied Psychology, Clinical Psychology, Developmental and Educational Psychology, Experimental and Cognitive Psychology, Neuropsychology and Physiological Psychology, Psychology Miscellaneous and Social Psychology. The fact that one journal can be simultaneously included in both databases for JCR (SCI and SSCI) and SJR must be noted, and it can also be thematically classified into more than one category and quartiles. All relevant journal data were drawn by inquiring into the JCRs and SJR for 2014, 2015 and 2016 and subsequently entered into a database designed with Microsoft Access 2003.

\section{Results}

The total number of psychology journals included in the JCR (SCI and SSCI) databases for 2014-2016 was 598, 605 and 604 , respectively. In SJR database the number of psychology journals during the same period of time is 1053, 1060 and 1094.

Table 1 shows the distribution of journals by year during the years 2014, 2015 and 2016 that have been edited by a total of 42 countries and in circulation in two databases: JCR and SJR. The psychology journals included in the JCR databases (SCI and SSCI) during this period were edited by 28 countries, while during the same years in the SJR database the number of psychology journals were from 41 countries.

The United States and United Kingdom were the countries with the greatest number of journals included in JCR and SJR databases. Together they accounted for nearly the $80 \%$ and the $68 \%$ respectively, of the total of journals included in the databases. The Netherlands, Germany and Spain occupy the third, fourth and fifth position in the ranking of countries with a greater number of journals included in the JCR databases. While the Netherlands, Germany and France have this ranking in the SJR case.

$\underline{\text { Table } 1 . \text { Distribution of number of journals per editing country. }}$

\begin{tabular}{|c|c|c|c|c|c|c|}
\hline \multirow[b]{2}{*}{ Country } & \multicolumn{3}{|c|}{ JCR } & \multicolumn{3}{|c|}{ SJR } \\
\hline & 2014 & 2015 & 2016 & 2014 & 2015 & 2016 \\
\hline Argentina & 2 & 2 & 2 & 3 & 3 & 3 \\
\hline Australia & 5 & 5 & 5 & 9 & 10 & 6 \\
\hline Belgium & 2 & 2 & 2 & 7 & 6 & 5 \\
\hline Brazil & 1 & 1 & 1 & 18 & 19 & 20 \\
\hline Canada & 4 & 4 & 4 & 8 & 8 & 9 \\
\hline Chile & 1 & 1 & 1 & 2 & 2 & 3 \\
\hline Colombia & 2 & 2 & 2 & 7 & 7 & 7 \\
\hline Croatia & 0 & 0 & 0 & 4 & 4 & 4 \\
\hline Czech Republic & 1 & 1 & 1 & 2 & 2 & 3 \\
\hline Denmark & 1 & 1 & 1 & 2 & 2 & 1 \\
\hline Egypt & 0 & 0 & 0 & 1 & 1 & 2 \\
\hline France & 9 & 9 & 9 & 38 & 37 & 39 \\
\hline Germany & 34 & 28 & 27 & 50 & 49 & 55 \\
\hline Greece & 0 & 0 & 0 & 1 & 1 & 1 \\
\hline Hungary & 0 & 0 & 0 & 7 & 7 & 7 \\
\hline India & 0 & 0 & 0 & 5 & 5 & 5 \\
\hline Ireland & 0 & 0 & 0 & 2 & 2 & 2 \\
\hline Italy & 1 & 1 & 1 & 17 & 18 & 19 \\
\hline Japan & 2 & 2 & 2 & 7 & 7 & 7 \\
\hline Lithuania & 0 & 0 & 0 & 1 & 1 & 1 \\
\hline Macedonia & 0 & 0 & 0 & 1 & 1 & 1 \\
\hline Mexico & 1 & 1 & 1 & 5 & 6 & 5 \\
\hline Netherlands & 31 & 32 & 32 & 51 & 52 & 70 \\
\hline New Zealand & 1 & 1 & 1 & 5 & 5 & 5 \\
\hline Poland & 1 & 1 & 2 & 9 & 10 & 9 \\
\hline
\end{tabular}




\begin{tabular}{lccccccc}
\hline \multicolumn{1}{c}{ Country } & \multicolumn{3}{c}{ JCR } & & SJR \\
\cline { 1 - 5 } & 2014 & 2015 & 2016 & 2014 & 2015 & 2016 \\
\hline Portugal & 0 & 0 & 0 & 1 & 1 & 4 \\
Puerto Rico & 0 & 0 & 0 & 1 & 1 & 1 \\
Romania & 1 & 2 & 2 & 5 & 5 & 5 \\
Russian Federation & 2 & 2 & 2 & 3 & 3 & 3 \\
Saudi Arabia & 0 & 0 & 0 & 0 & 0 & 1 \\
Serbia & 1 & 1 & 1 & 1 & 1 & 2 \\
Slovakia & 1 & 1 & 1 & 1 & 1 & 1 \\
Slovenia & 0 & 0 & 0 & 1 & 1 & 2 \\
South Africa & 1 & 1 & 1 & 3 & 3 & 2 \\
South Korea & 0 & 0 & 0 & 1 & 1 & 1 \\
Spain & 12 & 12 & 12 & 30 & 30 & 27 \\
Sweden & 1 & 1 & 1 & 0 & 0 & 0 \\
Switzerland & 7 & 7 & 7 & 20 & 20 & 20 \\
Turkey & 1 & 1 & 1 & 4 & 4 & 4 \\
United Arab Emirates & 0 & 0 & 0 & 0 & 0 & 1 \\
United Kingdom & 126 & 133 & 133 & 267 & 267 & 247 \\
United States & 346 & 350 & 349 & 453 & 457 & 484 \\
\hline Total journals & $\mathbf{5 9 8}$ & $\mathbf{6 0 5}$ & $\mathbf{6 0 4}$ & $\mathbf{1 , 0 5 3}$ & $\mathbf{1 , 0 6 0}$ & $\mathbf{1 , 0 9 4}$ \\
\hline
\end{tabular}

Only 5 countries had more journals in the JCR-2016 than in the JCR-2014: The United Kingdom (7 journals), The United States (3 journals), The Netherlands (1 journal), Poland (1 journal) and Romania (1 journal). In the SJR database there are 14 countries that increase the number of psychology journals in the year 2016 compared to 2014. In this case, the journals were edited in The United States (31 journals), The Netherlands (19 journals), Germany (6 journals), Portugal (3 journals), Brazil (2 journals), Italy (2 journals), Canada (1 journal), Chile (1 journal), Czech Republic (1 journal), Egypt (1 journal), France (1 journal), Saudi Arabia (1 journal), Slovenia (1 journal) and the Arab Emirates (1 journal).

It is also observed the presence of journals in some countries that decrease in the JCR-2016 regarding the year 2014 , as it is the case of Germany, which goes from 34 journals in 2014 to 27 in 2016. It is also noticed the presence of psychology journals in the SJR database decreasing in the year 2016 compared to 2014. In this case, there are 6 countries affected: the United Kingdom (20 journals), Australia (3 journals), Spain (3 journals), Belgium (2 journals), Denmark (1 journal) and South Africa (1 journal).

The function of periodical publications is to be the main channel of communication among the scientific community. This mean must be permanent, punctual, rigorous and transparent, becoming the official and public record of knowledge, certifying its authorship; that the publicized respects the scientific methods and ensuring that the contents have been previously submitted to the consideration of other scientists we call peers (Ruiz-Pérez, Martin-Martin \& Delgado López-Cozar, 2015). Scientific journals play a fundamental role in the different stages of research activity. They are the starting point of any investigation, because they provide the state of knowledge in a given topic and facilitate the dis- semination of new knowledge that will be the basis for future research by other scientists. But publications also fulfil other functions, such as establishing the priority of a particular discovery and rewarding researchers for their contributions through citations peers (Bordons, 2004).

Bibliometric or scientific production studies are currently an essential tool for the analysis of research developed in different countries. The impact factor and other bibliometric indexes are currently used in various countries to evaluate the production and/or quality of scientific research. The recognition given in the different evaluation processes to the publications collected in prestigious journals, such as those included in the JCR, is an effective stimulus to increase the international visibility of a country's research (Sierra, BuelaCasal, Bermúdez \& Santos-Iglesias, 2009) and the journals have had to develop different strategies to be attractive to the researcher and increase their presence in databases of excellence, such as JCR or SJR. However, the current criteria for the promotion of university professors and scientists from some countries, such as Spain, are based almost exclusively on research activities and, in some disciplines, such as psychology, it is necessary to have articles published in journals included in the bases of JCR data located in quartiles 1 and 2 (CNEAI, 2016) in its subject category, which can have negative consequences for the survival of the journals of this discipline. Tables 2 and 3 show the total number of psychology journals that each country has in JCRs and SJRs for the years 2014, 2015 and 2016 in different quartiles. In some cases, the total number of journals distributed by quartiles exceeds the actual number of publications that this country has, as a result of which a journal can be classified into different subject categories and can occupy different positions and quartiles in each of the categories in which it is included.

When analysing the distribution of the number of psychology journals, by country of edition and quartiles in the JCR databases (see Table 2), it is observed that during the year 2014 only 7 countries (Canada, Germany, Netherlands, Spain, Switzerland, United Kingdom and United States) are those that have a psychology journal located in the quartile 1 . In 2015, the number of countries with journals in quartile 1 decreases to 6 (Canada, Germany, Netherlands, Switzerland, United Kingdom and United States) and in 2016, the number of countries with psychology journals in the quartile increases to 8 (Australia, Germany, Netherlands, Romania, Spain, Sweden, United Kingdom and United States). The number of countries that have psychology journals located in quartile 2 it is 8 during the years 2014 and 2015, and 12 countries during the year 2016. In the third quartile, during the three years analysed, there are 11 countries that have any journal occupying this position. Finally, as shown in the table, it is in quartile 4, where there are psychology journals from a larger number of countries. 
Table 2. Distribution of number of psychology journals by country and quartile in JCR databases (2014-2016).

\begin{tabular}{|c|c|c|c|c|c|c|c|c|c|c|c|c|}
\hline \multirow{3}{*}{ Country } & \multicolumn{12}{|c|}{ JCR } \\
\hline & \multicolumn{4}{|c|}{2014} & \multicolumn{4}{|c|}{2015} & \multicolumn{4}{|c|}{2016} \\
\hline & $\overline{\mathrm{Q} 1}$ & Q2 & Q3 & Q4 & Q1 & Q2 & Q3 & Q4 & Q1 & Q2 & Q3 & Q4 \\
\hline Argentina & & & & 2 & & & & 2 & & & & 2 \\
\hline Australia & & & 2 & 3 & & & 4 & 1 & 1 & 2 & 1 & 1 \\
\hline Belgium & & & 1 & 1 & & & & 2 & & & 2 & \\
\hline Brazil & & & & 1 & & & & 1 & & & & 1 \\
\hline Canada & 1 & 1 & 1 & 1 & 1 & 1 & 2 & & & 2 & & 2 \\
\hline Chile & & & & 1 & & & & 1 & & & & 1 \\
\hline Colombia & & & & 2 & & & & 2 & & & 1 & 1 \\
\hline Czech Republic & & & & 1 & & & & 1 & & & & 1 \\
\hline Denmark & & & & 1 & & & & 1 & & & & 1 \\
\hline France & & 1 & & 8 & & 1 & & 8 & & & 1 & 8 \\
\hline Germany & 1 & 8 & 9 & 17 & 1 & 6 & 10 & 19 & 1 & 4 & 5 & 19 \\
\hline Italy & & & & 1 & & & 1 & 1 & & & & 1 \\
\hline Japan & & & & 2 & & & 1 & 1 & & & & 2 \\
\hline Mexico & & & & 1 & & & & 1 & & & & 1 \\
\hline Netherlands & 6 & 16 & 10 & 7 & 11 & 14 & 7 & 7 & 6 & 13 & 5 & 11 \\
\hline New Zealand & & & & 1 & & & & 1 & & & & 1 \\
\hline Poland & & & 1 & & & & 1 & & & 1 & & 1 \\
\hline Romania & & & & 1 & & & & 2 & 1 & 1 & 2 & \\
\hline Russian Federation & & & & 2 & & & & 2 & & & & 2 \\
\hline Serbia & & & & 1 & & & & 1 & & & & 1 \\
\hline Slovakia & & & & 1 & & & & 1 & & 1 & & \\
\hline South Africa & & & & 1 & & & & 1 & & 1 & & \\
\hline Spain & 1 & 2 & 3 & 7 & & 3 & 1 & 8 & 1 & 4 & 3 & 7 \\
\hline Sweden & & & 1 & & & 1 & & & 1 & & & \\
\hline Switzerland & 3 & 2 & 1 & 1 & 4 & & 2 & 1 & & 1 & 3 & 3 \\
\hline Turkey & & & & 1 & & & & 1 & & & & 1 \\
\hline United Kingdom & 30 & 43 & 34 & 27 & 29 & 46 & 40 & 21 & 40 & 35 & 34 & 30 \\
\hline United States & 104 & 89 & 99 & 74 & 101 & 95 & 93 & 84 & 91 & 95 & 97 & 70 \\
\hline
\end{tabular}

When analysing the distribution of the psychology journals collected in the SJR database (see Table 3), by editing country and quartile, it is observed that the number of countries that have journals located in quartile 1, is slightly higher than those of the JCR databases. In 2014, in the SJR there are 9 countries that have journals in quartile 1 (Canada, Germany, Italy, Netherlands, Portugal, Spain, Switzerland, United Kingdom and United States), a figure that increases in 2015 to 11 countries (Belgium, Canada, France, Germany, Hungary, Netherlands, Portugal, Spain, Switzerland, United Kingdom and United States) and to 13 countries in 2015 (Belgium, Canada, France, Germany, Hungary, Italy, Japan, Netherlands, New Zealand, Spain, Switzerland, United Kingdom and United States). The number of countries that have psychology journals located in quartile 2 is also slightly higher in the SJR databases. In this case, there are 11 countries that have journals in quartile 2 during 2014 and 18 the number of countries during the years 2015 and 2016, although the countries are not always the same ones. I.e.: Australia and France have journals in quartile 2 in the SJR-2015 and nevertheless, they do not have them during the year
2016. On the contrary, India and South Korea in the SJR of 2015 did not have any psychology journal in quartile 2 and yet they happen to have it in the SJR of the year 2016. As expected, where there is a greater number of journals per countries of edition is in quartiles 3 and 4 . In quartile 3, we find that in the SJR of the year 2014 there are journals from 25 countries, number that increases in the years 2015 and 2016 (33 and 34 countries respectively). Quartile 4, stands out for being the one that has psychology journals from a greater number of countries, 35 in the SJR of 2014, 34 in the 2015 and 35 in the 2016.

The United States and the United Kingdom stand out, since they are the countries that have the most journals in quartile 1. The United States has more journals in quartile 1 than in the other quartiles, the same applies to the United Kingdom, during the years 2014 and 2015. However, in the SJR of 2016, the number of English journals in quartile 2 is higher than the number of journals in quartile 1 . The Netherlands also stands out, because in the SJR of 2016 the journals in quartile 1 were larger than the number of journals that it had in the other quartiles. 
Table 3. Distribution of number of psychology journals by country and quartile in SJR databases (2014-2016).

\begin{tabular}{|c|c|c|c|c|c|c|c|c|c|c|c|c|}
\hline \multirow[t]{3}{*}{ Country } & \multicolumn{12}{|c|}{ SJR } \\
\hline & \multicolumn{4}{|c|}{2014} & \multicolumn{4}{|c|}{2015} & \multicolumn{4}{|c|}{2016} \\
\hline & Q1 & Q2 & Q3 & Q4 & Q1 & Q2 & Q3 & Q4 & Q1 & Q2 & Q3 & Q4 \\
\hline Argentina & & & 1 & 2 & & & 3 & & & & 3 & \\
\hline Australia & & & 4 & 5 & & 1 & 2 & 4 & & & 3 & 6 \\
\hline Belgium & & 1 & 2 & 4 & 1 & & 2 & 4 & 1 & & 2 & 3 \\
\hline Brazil & & & 7 & 11 & & & 7 & 12 & & & 6 & 14 \\
\hline Canada & 1 & 3 & 1 & 4 & 1 & 3 & 6 & 2 & 1 & 3 & 3 & 3 \\
\hline Chile & & & 2 & & & 1 & 1 & 1 & & 1 & 3 & \\
\hline Colombia & & & 2 & 5 & & 1 & 4 & 3 & & 1 & 3 & 5 \\
\hline Croatia & & & & 4 & & & 2 & 3 & & & 1 & 4 \\
\hline Czech Republic & & & 1 & 1 & & 1 & 1 & & & 1 & 1 & 2 \\
\hline Denmark & & & & 2 & & & & 1 & & & & 1 \\
\hline Egypt & & & 1 & & & 1 & & & & 1 & 1 & 2 \\
\hline France & & & 7 & 31 & 1 & 3 & 10 & 33 & 1 & & 9 & 33 \\
\hline Germany & 12 & 8 & 18 & 20 & 12 & 17 & 25 & 18 & 14 & 12 & 24 & 25 \\
\hline Greece & & & & 1 & & & & 1 & & & & 1 \\
\hline Hungary & & 1 & 2 & 4 & 1 & 1 & 4 & 4 & 1 & 1 & 4 & 4 \\
\hline India & & 1 & 1 & 3 & & & 2 & 2 & & 1 & 2 & 3 \\
\hline Ireland & & & & 2 & & & & 2 & & & 1 & 2 \\
\hline Italy & 1 & & 7 & 9 & & 1 & 9 & 8 & 1 & 2 & 9 & 12 \\
\hline Japan & & & & 7 & & & 5 & 5 & 1 & & & 6 \\
\hline Lithuania & & & & 1 & & & 15 & 1 & & & & 1 \\
\hline Macedonia & & & & 1 & & & & 1 & & & & 1 \\
\hline Mexico & & & & 5 & & & & 6 & & & 1 & 5 \\
\hline Netherlands & 20 & 10 & 12 & 12 & 18 & 10 & 10 & 14 & 39 & 26 & 25 & 12 \\
\hline New Zealand & & & 5 & & & 2 & 2 & 1 & 1 & 1 & 3 & 1 \\
\hline Poland & & 1 & 1 & 7 & & 2 & 3 & 6 & & 2 & 2 & 8 \\
\hline Portugal & 1 & & & 1 & 1 & 1 & 1 & 2 & & 2 & 2 & 1 \\
\hline Puerto Rico & & & & 1 & & & 1 & & & & & 1 \\
\hline Romania & & & 2 & 3 & & & 2 & 4 & & & 3 & 4 \\
\hline Russian Federation & & & 1 & 2 & & & 1 & 2 & & & 1 & 2 \\
\hline Saudi Arabia & & & & & & & 1 & & & & 1 & \\
\hline Serbia & & & 1 & & & & 1 & 1 & & & 1 & 1 \\
\hline Slovakia & & & & 1 & & & & 1 & & & 1 & \\
\hline Slovenia & & & & 1 & & & & 1 & & & & 2 \\
\hline South Africa & & & 1 & 2 & & & 1 & 1 & & & 2 & \\
\hline South Korea & & & & 1 & & & 1 & & & 1 & 1 & 1 \\
\hline Spain & 2 & 5 & 10 & 13 & 2 & 5 & 14 & 12 & 3 & 7 & 14 & 9 \\
\hline Switzerland & 5 & 4 & 3 & 8 & 6 & 6 & 5 & 7 & 5 & 6 & 8 & 7 \\
\hline Turkey & & & & 4 & & & 1 & 4 & & & 2 & 3 \\
\hline United Arab Emirates & & & & & & & 1 & & & & 1 & \\
\hline United Kingdom & 117 & 88 & 65 & 35 & 103 & 76 & 88 & 48 & 108 & 112 & 90 & 56 \\
\hline United States & 233 & 137 & 99 & 61 & 261 & 266 & 114 & 53 & 258 & 352 & 265 & 65 \\
\hline
\end{tabular}

\section{Discussion and conclusions}

The growth of scientific research in recent years has prompted the development and implementation of various indicators to measure the importance of research for the scientific community. Scientific journals are decisive instruments for the development of a society, and they are the measure par excellence of scientific communication. This seems to be reason for researchers to publish their papers in journals that provide their results with both visibility and impact, i.e. recognition for their contribution to the development of science (Gaillard, 1992).
However, science in many peripheral countries is published by national journals that are underrepresented in international databases, and the scientists who publish their work in mainstream journals -a relatively small group- make up a scientific elite that is able to influence science policy. A common feature in this group of scientists is their lack of interest in publishing in national journals or in languages other than English. This group is becoming increasingly larger, not for their real prestige but for their longing to obtain it; they have no incentive in publishing in unindexed national journals, as they are no use for their careers or to be awarded projects. Partly caused by evaluation criteria in developing countries (higher scores for scientists publishing in interna- 
tional journals), this widespread phenomenon is indeed a complex one. The envisaged positive effects for countries with an emerging psychology will only be ascertained over time. Publishing strategies also differ across countries and scientific disciplines (Gastel, 2001).

In the case of psychology, as said earlier, academic responses should focus on presenting work to colleagues from the same field, thus contributing to scientific knowledge; yet, one of the most important criteria when choosing a journal for publication is its impact factor, to the extent that papers are sometimes built bearing in mind the journal targeted by the authors. In some countries, like Spain, this is the outcome of evaluation and promotion criteria applied to researchers and lecturers working in this discipline. In some cases, a choice is made for the option that ensures survival as researchers rather than the one with the greatest dissemination potential amongst experts in the subject. Without a doubt, this fact influences the selection of research lines within the discipline, since it seems preferable to focus on subjects with a greater coverage in journals of excellence which improves the prospects of publishing results in journals with a better quartile. This is also likely to be related to the increase in multidisciplinary journals within psychology, as more multidisciplinary psychology journals are found in quartile 1 than in any other specialised subject areas.

An aspect worth reflecting about is the situation of Ibero-American journals in the databases of the Journal Citation Reports (JCR). The scarce presence of Spanish and Ibero-American journals in the positions of excellence (quartiles 1 and 2), in the JCR and SJR databases draws attention.

This study aims to provide an overview of the situation of psychology journals in the JCR and SJR in 2014, 2015 and 2016, and to show that some of the strategies implemented by some countries to enhance the visibility of their scientific journals can be seriously affected by current researchevaluation criteria. These criteria influence researchers in so far as they try to publish their work in journals outside their speciality but better regarded by evaluation agencies. Evaluators have expressly noted that they simply consider the journal's quartile, overlooking other aspects (quality of the article, research subsidised or not, sample size, relationship with researcher profile...), which might bring out negative consequences not only for the scientific community itself, who notice the growing dispersion of the scientific literature, but also for publishers; after the efforts made to enter the international scene, they see how authors choose their journals not for their best practices or their specialty but for their position on the rank. Interestingly, it may be the case that publishing in a high impact factor journal may be counterproductive for the authors and the journals themselves if they are not the ones that the researchers to whom the studies are directed read. If a document is not read by the audience to which it may be interested and addressed, it may go unnoticed and, therefore, not receive appointments and, in that case, this situation would affect not only the authors of the work, but also the impact of the magazine where it has been published.
As noted by Gastel (2001), it should not be forgotten that, over and above the obsession with impact factors, the most appropriate journal to publish a work will depend on the target audience.

In view of the results presented in the present work, future research will have to answer questions regarding the effect of the policies of scientific evaluation and accreditation of university professors in Spain on national and even LatinAmerican publications. Questions like, to what extent this evaluation system has generated the exodus, when publishing its works, of great researchers towards non-national publications that are better positioned in JCR, or if the number of Spanish researchers that publish in non-national journals located between the first two quartiles has increased, and at what price, that is, how much does it costs economically to publish in one of these journals, converting what should be shared scientific findings among researchers in a mere business in which researchers invest lost fund, in building a curriculum.

The current system of evaluation, marginalises local or national studies, being not less relevant, and at the same time, relegates national and Latin-American journals to secondary positions. In addition, it condemns the publications whose publishers are Universities or other institutions such as Foundations - which are about to disappear - by not being able to compete with the lobby of the large publishers that distribute most of the publications indexed in the JCR of the WoS.

In the case of Spanish journals, only 13 of them in 2014 and 9 in 2015 were included in the JCR of Psychology, barely $2 \%$ of the total number of journals. Publications that are indexed on a largely Anglo-Saxon basis, taking into account that in 2014 of the 598 indexed journals, 500 of them were published in an English-speaking country (USA, England, Australia, Canada and New Zealand). This circumstance opens again the range of new questions, as if there is a glass ceiling of the national and Latin-American publications in the JCR of the WoS according to the quartile occupied by a journal, even more so when in the area of Psychology there is no Latin-American journals in the first quartile at the 2015 JCR.

Bearing in mind that the main consumers of scientific results, attending to the citations, are the local or national researchers themselves, it even aggravates more the situation of the national journals in an Anglo-Saxon database, in which hardly these works are going to obtain a number of citations that allow to increase the impact factor of the journal, and therefore be in the first quartiles.

Another consequence that must be analysed is the extent to which this evaluation system is associated with the nonspecialization of researchers along with the growth of multidisciplinary journals in the JCR, giving rise to a multidisciplinary researcher profile, probably in the first moments of its research career until consolidating position. And in turn, multidisciplinarity entails the paralysis in the growth of other areas of Psychology, as it could be in the thematic categories 
of Psychology Psychoanalysis, Psychology Biological or Psychology Mathematical, where only 14 journals are part of them compared to the 119 journals of the Psychology Multidisciplinary category.

The current evaluation system, in addition, conditions even the documentary typology, condemning the monographs or book chapters to the disappearance, in front of the publication of articles in journals.

There is no doubt that a critical reflection is required on the consequences of the policy of scientific evaluation in

\section{References}

Bordons, M. (2004). Hacia el reconocimiento internacional de las publicaciones científicas españolas. Revista Española de Cardiología, 57(9), 799-802.

Brody, S. (2013). Impact factor: Imperfect but not yet replaceable. Scientometrics, 96, 255-257.

Buela-Casal, G. (2014). Pathological publishing: A new psychological disorder with legal consequences? The European Journal of Psychology Applied to Legal Context, 6, 91-97.

Buela-Casal, G. (2010). Índice de impacto de las revistas científicas e indicadores para medir el rendimiento de los investigadores. Revista de Psicodidáctica, 15, 3-19.

Buela-Casal, G. \& Sierra, J. C. (2007). Criterios, indicadores y estándares para la acreditación de profesores titulares y catedráticos de Universidad. Psicothema, 19, 537-551.

Buela-Casal, G. \& Zych, I. (2012). What do the Scientists think about the impact factor? Scientometrics, 92, 281-292.

Buela-Casal G., Quevedo, R. \& Guillén, A. (2015). Ranking 2013 de investigación de las universidades públicas españolas. Psicothema, 27, 317-326.

Camí, J. (1997). Impactología: diagnóstico y tratamiento. Medicina Clínica, 109, 515-524.

Comisión Nacional Evaluadora de la Actividad Investigadora (CNEAI) (2016). Criterios de evaluación 2016. Retrieved from: http:// www.mecd.gob.es/ministeriomecd/organizacion/organismos/cneai/criterios-evaluacion.html

Fernández-Ríos, L. \& Rodríguez-Díaz, F. J. (2014). The "impact factor style of thinking": A new theoretical framework. International Journal of Clinical and Health Psychology, 14, 154-160.

Gaillard, J. (1992). Use of publication list to study scientific production and strategies of scientists in developing countries. Scientometrics, 29, 57-73.

García, A. (2014). La tiranía del factor de impacto. Actualidad en Farmacología y Terapéutica, 12, 8-13.

Gastel, B. (2001). Assessing the impact of investigators work: Beyond impact factors. Canadian Medical Association Journal, 48, 941-945.

Gordillo, V., Gonzáles-Marqués, J. \& Muñiz, J. (2004). La evaluación de proyectos de investigación por la ANEP. Psicothema, 16, 343349.

Jiménez-Contreras, E., Robinson-García, N. \& Cabezas-Clavijo, A. (2011). Productividad e impacto de los investigadores españoles: Umbrales de referencia por áreas científicas. Revista Española de Documentación Científica, 34, 505-526.

Laufer, M. (2013). Editorial. Los valores intangibles de las publicaciones científicas. Interciencia, 38, 322

Medina-Muñoz, J. \& Estrada-Lorenzo, J. M. (2015). Citas, revistas y autores: Claves para la evaluación de la producción científica en ciencias de la salud. FisioGlía, 2, 9-13.

Moed, H. F., Colledge, L., Reedijk, J., Moya-Anegón, F., GuerreroBote, V., Plume, A. \& Amin, M. (2012). Citation-based metrics are
Spain, even more so when the Spanish University is inserted in the so-called European Higher Education Area following the Bologna process, and nevertheless it evaluates the quality of its researchers according to the criteria set by American specifications in scientific publications, not opening as it should be expected, the door to other journal bases that collect publications that are closer culturally, socially and politically to the European space.

appropriate tools in journal assessment provided that they are accurate and used in an informed way. Scientometrics, 92, 367-389.

Moreno-Pulido, A., López-González, M. A., Rubio-Garay, F., Saúl, L. A. \& Sánchez-Elvira-Paniagua, A. (2013). Evaluación de las revistas españolas de ciencias sociales en el Journal Citation Reports (2006-2010) y su valoración como indicio de calidad en la normativa evaluadora española. Revista Española de Documentación Científica, 36(3), 1-15.

Musi-Lechuga, B., Olivas-Ávila, J. \& Buela-Casal, G. (2009). Producción científica de los programas de doctorado en psicología clínica y de la salud en España. International Journal of Clinical and Health Psychology, 9, 167-173.

Olivas-Ávila, J. \& Musi-Lechuga, B. (2010). Análisis de la producción de los profesores funcionarios de Psicología en España en artículos de revistas de la Web of Science. Psicothema, 22, 909-916.

Ortiz de Urbina, M. \& Mora, E. (2013). El sistema de acreditación del profesorado a través del Programa ACADEMIA: Evolución y cambios. Revista Española de Documentación Cientifica, 36, 1-8.

Osca-Lluch, J. (2005). Some considerations on the use of the impact factor of scientific journals as a tool to evaluate research in psychology. Scientometrics, 65, 189-197.

Perceval, J. \& Fornieles, J. (2008). Confucio contra Sócrates. La perversa relación entre la investigación y la acreditación. Anàlisi, 6, 213224.

Pudovkin, A. I. \& Garfield, E. (2012). Rank normalization of impact factors will resolve Vanclay's dilemma with TRIF. Scientometrics, 92, 409-412.

Ruiz-Pérez, R., Martin-Martin, A. \& Delgado López-Cózar, E. (2015). Las revistas universitarias en el marco de los criterios de evaluación de la actividad investigadora. Revista Española de Documentación Cientifica, 38 (2)e081. doi: http://dx.doi.org/10.3989/redc.2015.2.1191.

Ruiz-Pérez, R., Delgado, E. \& Jiménez-Contreras, E. (2006). Criterios del Institute for Scientific Information para la selección de revistas científicas. Su aplicación a las revistas españolas: metodología e indicadores. International Journal of Clinical and Health Psychology, 6, 401 424.

Sierra, J. C., Buela-Casal, G., Bermúdez, M. P. \& Santos-Iglesias, P. (2009). Importancia de los criterios e indicadores de evaluación y acreditación del profesorado funcionario universitario en los distintos campos de conocimiento de la UNESCO. Revista de Universidad y Sociedad del Conocimiento, 6(3), 49-58.

Torres-Salinas, D. \& Cabezas-Clavijo, Á. (2013). Cómo publicar en revistas científicas de impacto: consejos y reglas sobre publicación científica. EC3 Working Papers, 13. Retrieved from: https:/ / ec3metrics.com/ wp-content/ uploads/2013/07/2ART\%C3\%8DCULO-C\%C3\%B3mo-Publicar-en-RevistasCient $\%$ C3\%ADficas-de-Impacto_Consejos-y-Reglas-sobrePublicaci $\%$ C3\%B3n-Cient $\%$ C3\% ADfica.pdf

Torres-Salinas, D., Delgado-López-Cózar, E., García-Moreno-Torres, J. \& Herrera, F. (2011). Rankings ISI de las universidades españo- 
las según campos científicos: descripción y resultados. El Profesional de la Información, 20, 111-122.
Van Diest, P. J., Holzel, H., Burnett, D. \& Crocker, J. (2001). Impactitis: New cures for an old disease. Journal of Clinical Pathology, 54(11), $817-819$. 
anales de psicología / annals of psychology, 2019, vol. $35, \mathrm{n}^{\circ} 1$ (january) 